\title{
Experimental and Numerical Simulation Frequency Characteristics of L-Shaped Waveguide-Slot Membranes Bandpass Filters
}

\author{
Natalia A. Kopylova*a,b, Alexei F. Kopylov', \\ Dmitri K. Ogorodnikov and Denis A. Nesterov ${ }^{b}$ \\ aJoint Stock Company "Scientific-Production Enterprise "Radiosvyaz" \\ 19 Dekabristov Str., Krasnoyarsk, 660021, Russia \\ ${ }^{b}$ Siberian Federal University \\ 79 Svobodny, Krasnoyarsk, 660041, Russia
}

Received 31.05.2018, received in revised form 14.06.2018, accepted 13.07.2018

The article presents the results of experimental research and numerical simulation of the amplitude-frequency characteristics $(A F C)$ of the voltage transmission ratio (voltage gain) $|K u|$ and frequency characteristics of the voltage standing wave ratio from the input (input VSWR) to three bandpass filters on the waveguide-slot membranes (WSM) with L-shaped resonance slot: to the single stage, to the three stages and to the four stages. The filter designs are given in article. The results of numerical simulation and experimental study show that in the frequency range 5,0...8,5 GHz filters provide attenuation behind the pass band up to $30 \mathrm{~dB}$ at the level of the introduced losses in the pass-band from 0,2 to 1,0 dB. The values of the calculated and experimental input VSWR in the filter bandwidth of pass-band are from 1,1 to 1,74 relative units $(r . u$.) and in the stop bands from 2 to $300 r$ r. u. The authors believe that using of waveguide-slot membranes will significantly reduce the overall dimensions of microwave bandpass and bandstop filters in the middle of the centimeter wavelength range.

Keywords: bandpass filter, waveguide-slot membranes (WSM), L-shaped resonant slot.

Citation: Kopylova N.A., Kopylov A.F., Ogorodnikov D.K., Nesterov D.A. Experimental and numerical simulation frequency characteristics of 1-shaped waveguide-slot membranes bandpass filters, J. Sib. Fed. Univ. Eng. technol., 2018, 11(6), 635-644. DOI: $10.17516 / 1999-494 X-0081$.

(C) Siberian Federal University. All rights reserved

This work is licensed under a Creative Commons Attribution-NonCommercial 4.0 International License (CC BY-NC 4.0).

* Corresponding author E-mail address: kopaph@yandex.ru 


\title{
Экспериментальные и расчетные
}

\section{частотные характеристики полосно-пропускающих фильтров на Г-образных волноводно-щелевых мембранах}

\author{
Н.А. Копылова ${ }^{a, \tilde{\sigma}}$, А.Ф. Копылов ${ }^{\tilde{\sigma}}$, \\ Д.К. Огородников ${ }^{\tilde{0}}$, Д.А. Нестеров ${ }^{0}$ \\ ${ }^{a}$ АО «Научно-производственное предприятие «Радиосвязь» \\ Россия, 660021, Красноярск, ул. Декабристов, 19 \\ ${ }^{6}$ Сибирский федеральный университет \\ Россия, 660041, Красноярск, пр. Свободный, 79
}

В статье представлень результаты экспериментального исследования и численного моделирования амплитудно-частотных характеристик (АЧХ) коэффициента передачи напряжения $|K u|$ и частотных характеристик коэффициента стоячей волны по напряжению со входа (входной КСВН) для трех полосовых фильтров, выполненных на волноводно-щелевых мембранах (ВЩМ) с Г-образной резонансной щелью: однокаскадного, трехкаскадного, и четырехкаскадного. В статье приведень конструкиии фильтров. Результать численного моделирования и экспериментальных исследований показывают, что в диапазоне частот 5..8,5 ГГи фильтры обеспечивают затухание за полосой пропускания до 30 дБ при уровне вносимыхпотерь вполосе пропускания от 0,2 до 1 дБ. Значения расчетного иэкспериментального входных КСВН в полосе пропускания фильтра составляют от 1,1 до 1,74 относительных единиц (о. е.) а в диапазонах задерживания - от 2 до 300 о. е. Авторы полагают, что использование волноводно-щелевых мембран позволит значительно уменьшить габаритные размеры СВЧ полосно-пропускающих и полосно-заграждающих фильтров в середине сантиметрового диапазона длин волн.

Ключевые слова: полосно-пропускающчий фильтр, волноводно-щелевая мембрана (ВЩМ), Г-образная резонансная щель.

\section{Introduction}

Despite the wide application of miniature microstrip filters in microwave technology, interest in waveguide filters, in particular, made on the basis of combinations of waveguide sections and metal membranes [1-3], is observed in the development and study of filter structures of the microwave range.

In this paper we will focus on the study of the frequency characteristics of filters on thin metal membranes, which are perpendicular to the direction of propagation of the electromagnetic wave in the waveguide and called filters on waveguide-slot membranes (WSM) [4].

\section{Filter design}

The filters studied by us are made on alternating cascade-connected waveguide-slot membranes. The first of the studied filters is a single-stage structure with an L-shaped slot, the topological pattern of which is presented in Fig. 1.

WSM has a thickness of about $0,25 \mathrm{~mm}$ and clamped between two lengths of waveguide perpendicular to the direction of propagation of electromagnetic waves in the waveguide. The waveguide segments between which the membrane is clamped are the input and output waveguide- 


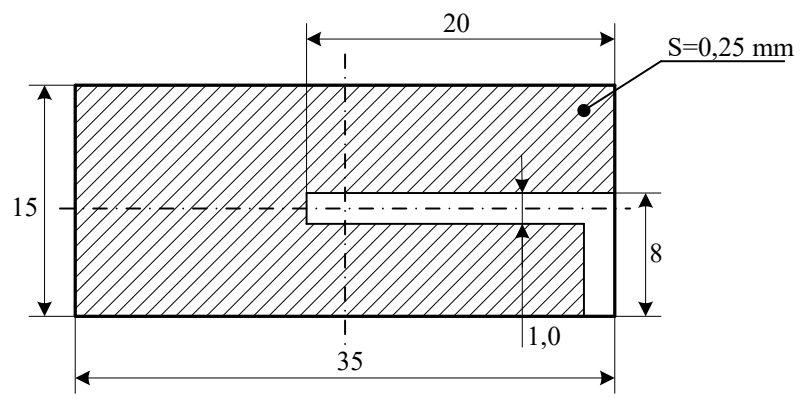

Fig. 1. Topology pattern of single metal membrane with L-shaped slot (scheme of construction of the first filter)

coaxial transitions (WCT) from the working section of the waveguide $35 \times 15 \mathrm{~mm}$ to the coaxial connector of type $\mathrm{N}$. The geometric dimensions of the L-shaped slot and its position on the plane of the membrane are selected as follows: the longest part of the slot has a size of $20 \mathrm{~mm}$, it is located in the center of the broad wall of the cross-section of waveguide and offset the edge of the narrow wall of the waveguide; further, the slot is bent and is positioned along the narrow wall of the waveguide from the center of the wide to the lower edge of the cross-section of the waveguide and has a length of $8 \mathrm{~mm}$; the width of the slot is $1 \mathrm{~mm}$.

The second filter has three stages. The scheme of its construction is shown in Fig. 2. The first stage is a WSM, similar to the one used in the first filter; the second stage is a waveguide spacer with a cross-section equal to the main cross-section of the waveguide $35 \times 15$ and $15 \mathrm{~mm}$ thick; the third stage is a new WSM, similar to that used in the first filter.

The scheme of construction of the third filter is shown in Fig. 3. The first stage of this filter is again a WSM, similar to the first filter and the first stage of the second filter; the second stage is a waveguide-slot membrane with a cross-section of 35x22 mm and a thickness of $6 \mathrm{~mm}$; the third stage is a waveguide spacer with a cross-section equal to the main cross-section of the waveguide $35 \times 15$ and a thickness $3 \mathrm{~mm}$; the fourth stage is again WSM, similar to that used in the first filter and in the third stage of the second filter.

\section{Results and discussion}

On Fig. 4, Fig. 5 and Fig. 6 are presented the results of numerical modeling and experimental measurement of the amplitude-frequency characteristics for the first, second and third filter, respectively. On the vertical axis, these figures show the values of the module voltage transmission ratio $\left|\mathrm{K}_{\mathrm{U}}\right|$ (voltage gain) in $\mathrm{dB}$, on the horizontal - the frequency values from 5 to $9 \mathrm{GHz}$. The experimental values of $\left|\mathrm{K}_{\mathrm{U}}\right|$ are plotted with bold points and connected by solid lines (curves 1 on Fig. 4, Fig. 5 and Fig. 6); the calculated points are marked with asterisks and are connected by a discontinuous curve (curves 2 on Fig. 4, Fig. 5 and Fig. 6). For the convenience of reading on top of the drawings is a table with experimental data values $\left|\mathrm{K}_{\mathrm{U}}\right|$ for the pass-band of the filters.

All the measurements were performed according to standard methods on a scalar measure of the modules of the transfer coefficients for voltage $\left|\mathrm{K}_{\mathrm{U}}\right|$ and VSWR analog type. Analysis of the AFC of all filters shows that these filters are pass-band with different selectivity. Of course, the selectivity of the filter increases with number of their units increasing.

$$
-637-
$$



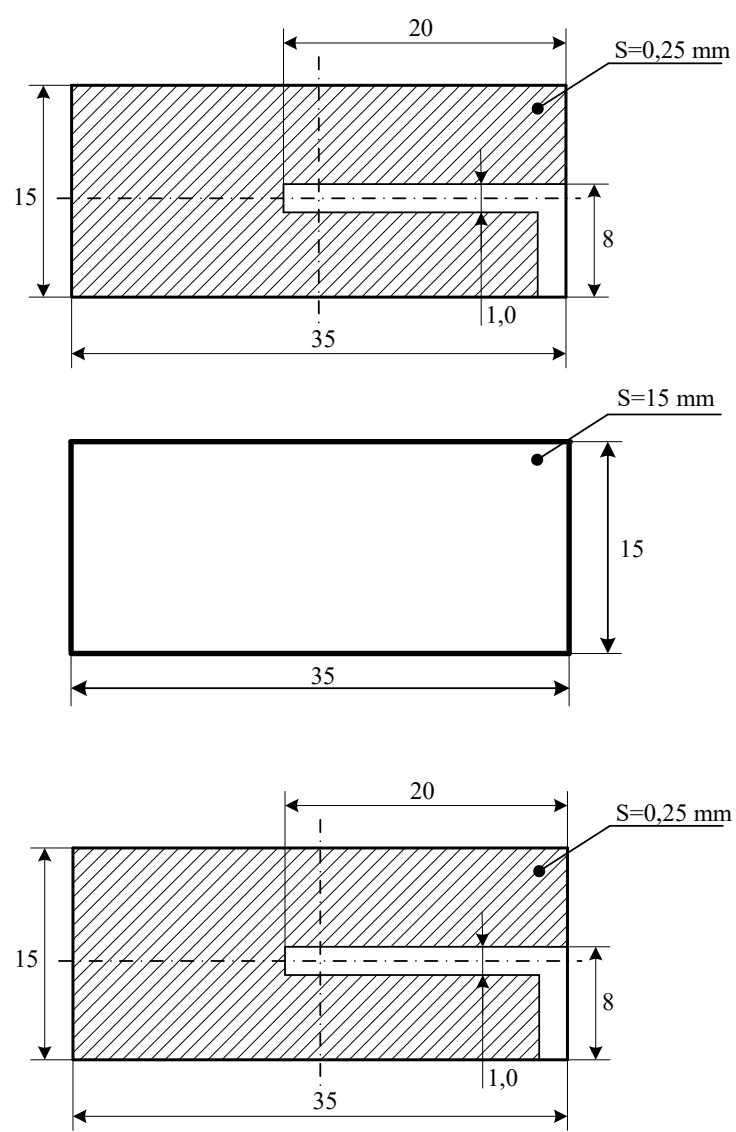

Fig. 2. Scheme of construction of the second filter

As seen in Fig. 4, the frequency response of a single WSM is a pass-band characteristic with a fairly pronounced attenuation for a stop-band of up to $15 \mathrm{~dB}$ at the extreme frequencies of the range as the results of experimental measurements and numerical simulation results. The ratio of the simulation results of the AFC and the experimental results can be determined as a complete qualitative match of these AFC with a certain shift of the experimental frequency response to the higher frequencies. At the same time, the loss in pass-band from $6,6 \mathrm{GHz}$ to $7,2 \mathrm{GHz}$ was $0,2 \ldots 1,3 \mathrm{~dB}$ (measured values).

Shown on Fig. 5 AFC of the three-stages filter demonstrates significantly more pronounced frequency selection properties than single-stages filter.

Thus, the attenuation at extreme frequencies in the investigated range in the three-stages filter reaches $26 \mathrm{~dB}$ to both according to the results of measurements and the results of calculations. When comparing the experimental and calculated curves the AFK of a three-stages filter there is a picture similar to that observed for the single-stage filter - a full qualitative agreement between the curves of frequency response with a slight shift of the experimental curve toward higher frequencies relative to the calculated. The loss in pass-band from $6,5 \mathrm{GHz}$ to $7,2 \mathrm{GHz}$ was $0,2 \ldots 1,2 \mathrm{~dB}$ (measured values).

The frequency-selective properties of the third filter are even more pronounced (see Fig. 6) - the measured attenuation value at the extreme upper frequency in the studied range reaches $29 \mathrm{~dB}$ with a significant narrowing of the stop-band relative to the first and second filters. 

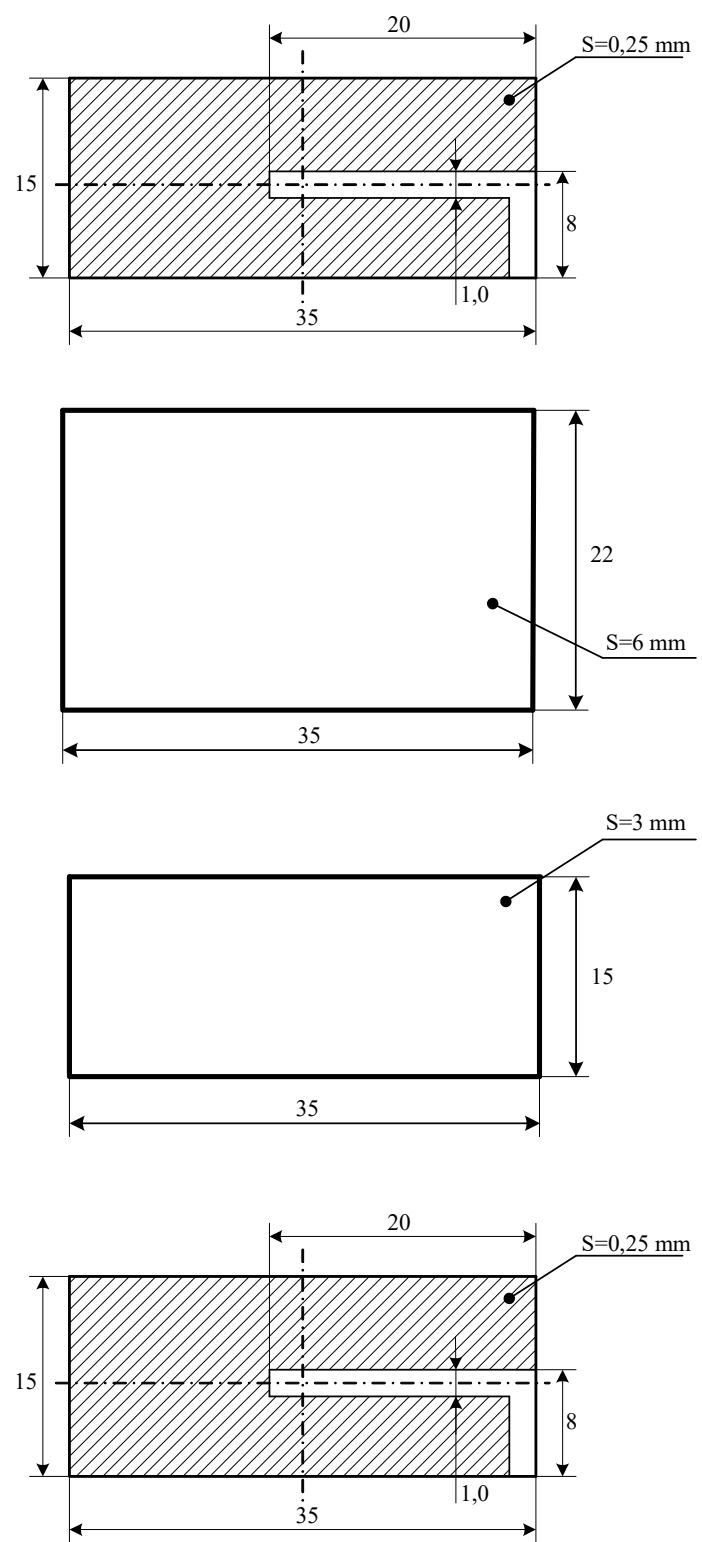

Fig. 3. Scheme of construction of the third filter

When comparing the experimental and calculated AFC curves of the four-stages filter, there is a violation of the observed trend for the single-stage and three-stages filters of their complete qualitative coincidence. This is evident in the upper cutoff frequencies at 7,2 ..8,5 GHz. In fact, the attenuation value obtained by calculation is about $70 \mathrm{~dB}$, while the experimental value reaches barely $30 \mathrm{~dB}$.

At the same time, the maximum attenuation frequencies differ significantly - for the experimental curve it is about 7,3 GHz, for the calculated curve it is about $8,3 \mathrm{GHz}$, and the pass-band values for the calculated and experimental curves differ significantly - for the calculated curve it is $6,25 \ldots 6,85 \mathrm{GHz}$, for the experimental curve it is $6,4 \ldots 6,75 \mathrm{GHz}$. When comparing the experimental and calculated data on the values of pass-band by the level of $\left|\mathrm{K}_{\mathrm{U}}\right|=-6 \mathrm{~dB}$ for the studied filters, the picture described below 


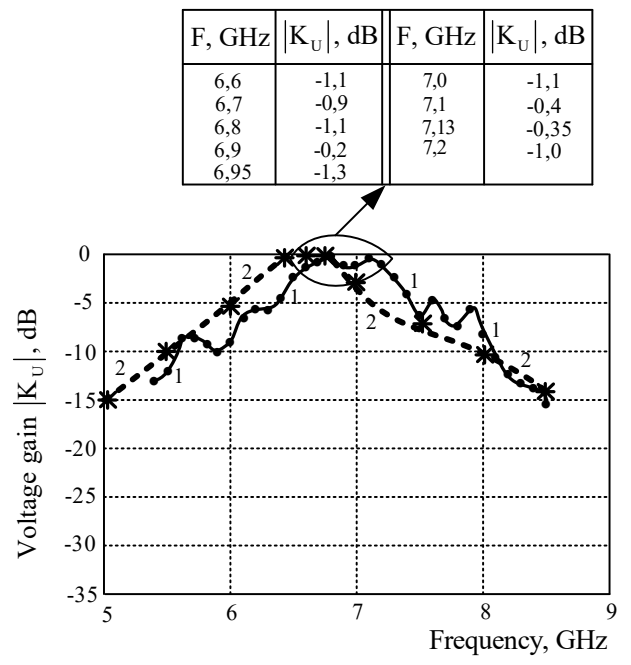

Fig. 4. AFC of the first single-stage filter: 1 - experimental results; 2 - numerical simulation results.

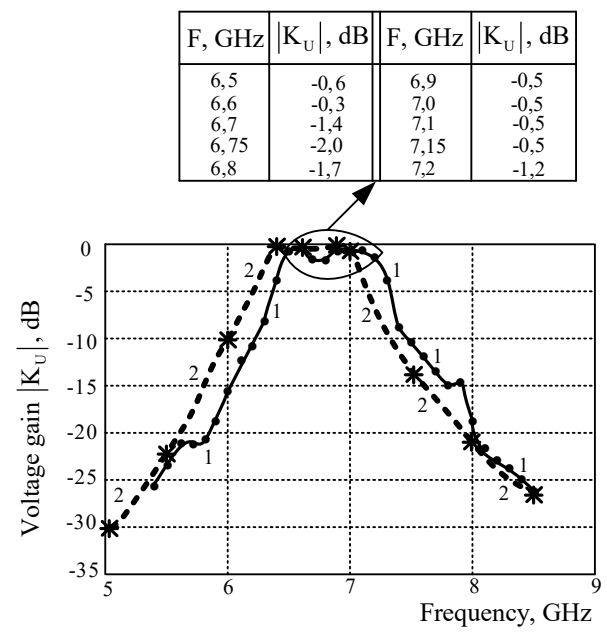

Fig. 5. AFC of the second three-stages filter: 1 - experimental results; 2 - numerical simulation results

is observed. According to experimental data for the first, single-stage filter, bandwidth of pass-band is located at frequencies from $6,15 \mathrm{GHz}$ to $7,5 \mathrm{GHz}$ and is $1,35 \mathrm{GHz}$; for the second, three-stages filter, bandwidth of pass-band is located at frequencies from $6,35 \mathrm{GHz}$ to $7,35 \mathrm{GHz}$ and is $1,0 \mathrm{GHz}$; for the third, four-stages filter, bandwidth of pass-band is located at frequencies from $6,25 \mathrm{GHz}$ to $6,85 \mathrm{GHz}$ and is $0,6 \mathrm{GHz}$. According to the calculated data, the corresponding values for the single-stage filter are: bandwidth of pass-band is located at frequencies from $5,95 \mathrm{GHz}$ to $7,05 \mathrm{GHz}$ and is about $1,1 \mathrm{GHz}$, for three-stages filter bandwidth of pass-band is located at frequencies from $6,2 \mathrm{GHz}$ to $7,1 \mathrm{GHz}$ and is about $0,9 \mathrm{GHz}$, for four-stages filter bandwidth of pass-band is located at frequencies from $6,05 \mathrm{GHz}$ to $7,15 \mathrm{GHz}$ and is $1,1 \mathrm{GHz}$.

A comparison of the calculated and experimental data shows that the difference in determining the $\mathrm{AFC}$ and the basic values characterizing the parameters of the four-stages filter becomes unacceptable 


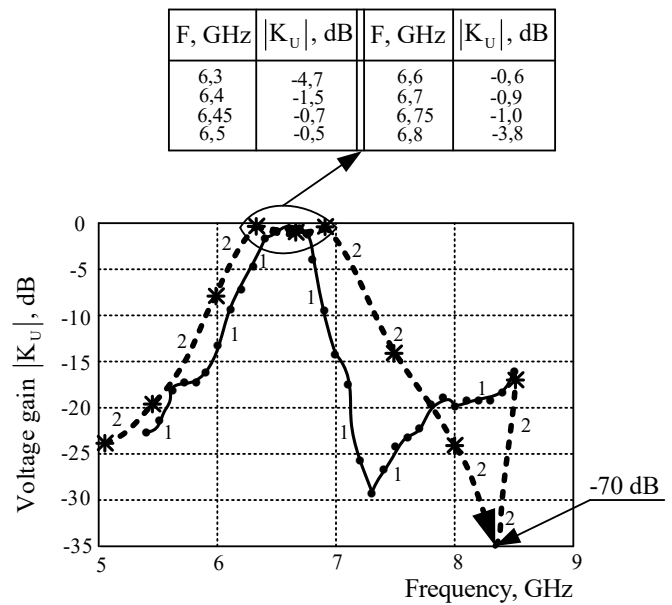

Fig. 6. AFC of the third four-stages filter: 1 - experimental results; 2 - numerical simulation results

and raises a number of questions on the topic of whether all significant factors significantly affecting the frequency response are included in the system in the calculation. We believe that the most important factor that was not taken into account in the numerical simulation is the presence of two WCT - input and output, which can significantly affect to the characteristics of the entire system. Naturally, in further research it is necessary to take into account the effect of this factor and include in the system when modeling its account.

Note that when comparing AFC between single-stage, three-stages and four-stages filters, it can be seen that with an increase in the number of stages, the attenuation behind the bandwidth, as well as an increase in the steepness of the filter AFC.

On Fig. 7, Fig. 8 and Fig. 9 are presented the results of experimental measurement and numerical modeling of the frequency characteristics of input VSWR for the three filters we studied: for the first, second and third filters, respectively. On the vertical axis, these figures show the values of the input VSWR of filters in relative units, on the horizontal - the frequency values from 5 to $9 \mathrm{GHz}$. The experimental values of input VSWR are plotted with bold points and connected by solid lines (curves 1 on Fig. 7, Fig. 8 and Fig. 9); the calculated points are marked with asterisks and are connected by a discontinuous curve (curves 2 on Fig. 7, Fig. 8 and Fig. 9). For more convenience, the footnotes in the lower parts of these drawings is a table with experimental data values input VSWR for the pass-band of the filters.

Analyzing the frequency characteristics of the input VSWR of single-stage filter (Fig. 7) and comparing them with the AFC of this filter (Fig. 4), it can be stated that the minimum values of the input VSWR in the bandwidth of pass-band from $6,6 \mathrm{GHz}$ to $7,2 \mathrm{GHz}$ are in the pre-s from 1,1 to 1,74 relative units, with the highest values of the input VSWR for the most significant attenuations $\left|\mathrm{K}_{\mathrm{U}}\right|$. The maximum values of the input VSWR are located to the filter stop-band at frequencies of 5, 3...6.5 GHz (lower stop-band) and 7.3...8.5 GHz (upper stop-band) and are in the range of 2 relative units to infinity also with the highest values of the input VSWR for the largest attenuations. Thus, there is a complete qualitative correspondence between the nature of the frequency dependencies $\left|\mathrm{K}_{\mathrm{U}}\right|(\mathrm{AFC})$ and the input VSWR of a single-stage filter. 


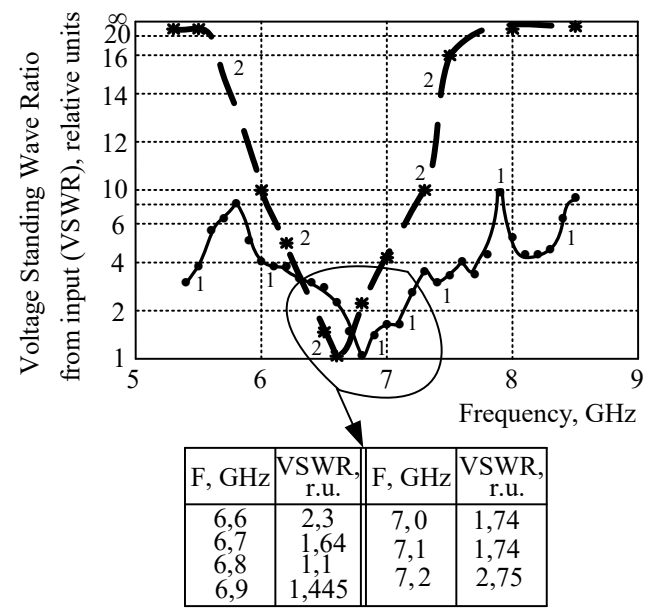

Fig. 7. Frequency characteristics of the input VSWR to first single-stage filter: 1 - experimental results; 2 - numerical simulation results

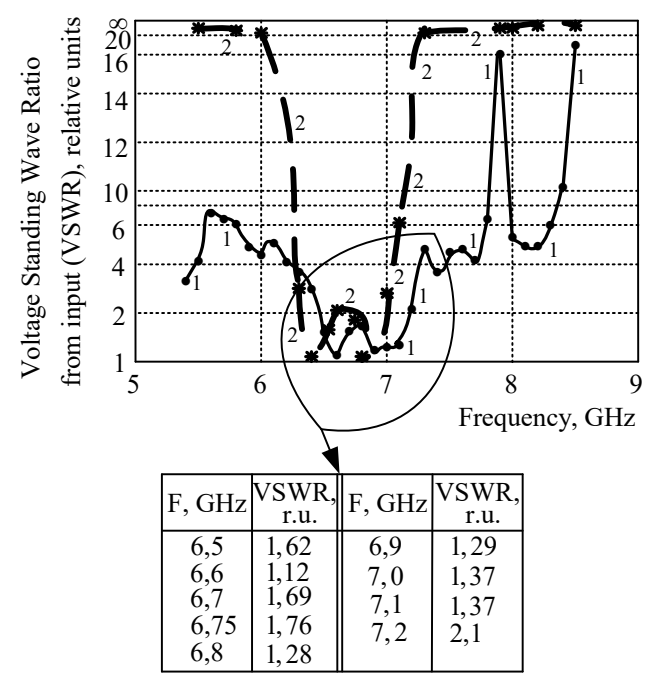

Fig. 8. Frequency characteristics of the input VSWR for the second three-stages filter: 1 - experimental results; 2 - numerical simulation results

However, it should be noted very significant differences between the calculated dependences of the input VSWR for single-stage filter (discontinuous line in Fig. 7) and experimental dependences of the VSWR input of the single-stage filter (solid line in Fig. 7). Most likely, this was due to two reasons: the first-because the factors affecting the filter characteristics were not taken into account during the calculations and at the moment the studies are not known to us (model inaccuracies, account inaccuracies); second, when conducting experimental studies related to the determination of the parameters of the reflected signals from those or other microwave devices, the accuracy is always the biggest problem, since the parameters associated with the reflection phase-frequency characteristics of these devices and practically difficult to correct because of the unpredictable 


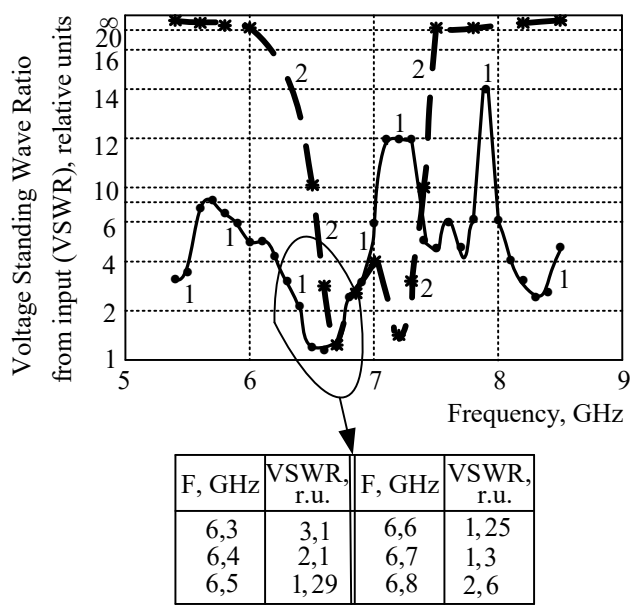

Fig. 9. Frequency characteristics of the input VSWR for the third four-stages filter: 1 - experimental results; 2 - numerical simulation results

nature of the additions and subtractions of phases in actual devices (inaccuracies the implementation of the devices).

On Fig. 8 presented the results of experimental measurement and numerical modeling of the frequency characteristics of input VSWR for the second three-stages filter.

As for the single-stage filter, when comparing the frequency characteristics of the input VSWR of this filter with its AFC (Fig. 5), there is a complete correspondence of these characteristics to each other, namely: the highest values of attenuation correspond to the highest values of the input VSWR, and vice versa, the lowest values of attenuations on the AFC correspond to the lowest values of the VSWR filter input.

At the same time, the comparison between the calculated frequency characteristics of the input VSWR three-stages filter (discontinuous line in Fig. 8) and experimental dependences of the threestages filter input VSWR (solid line in Fig. 8) shows the same trends as the comparison of similar frequency dependencies for a single-stage filter, namely: significant differences between the calculated and experimental dependences of the VSWR input both in the values of the input VSWR and in the frequencies of the location of the characteristic values of this parameter.

As for the numerical values of the input VSWR three-stages filter, it can be stated that the minimum values of the VSWR input in the bandwidth of pass-band from $6.5 \mathrm{GHz}$ to $7.1 \mathrm{GHz}$ are in the range from 1.12 to 1.37 relative units, with the highest values of VSWR for the largest attenuation $\left|\mathrm{K}_{\mathrm{U}}\right|$. The maximum values of the VSWR input correspond to the filter locking bands at frequencies of $5,3 \ldots 6.4 \mathrm{GHz}$ (lower stop-band) and 7.2...8.5 GHz (upper stop-band) and are in the range of 2 relative units to infinity also with the highest values of the VSWR input for the greatest attenuations of the frequency response.

Fig. 9 shows the input VSWR of the third, a four-stages filter.

As for the previous single-stage and three-link filters, when comparing the frequency characteristics of the VSWR output of this filter with its frequency response (Fig. 6), there is a complete correspondence of these characteristics to each other in the sense that the highest values of attenuation correspond to 
the highest values of input VSWR, and vice versa, the lowest values of attenuation on the frequency response correspond to the lowest values of input VSWR of filter. And again a comparison between the calculated frequency characteristics of the VSWR input four-stage filter (discontinuous line in Fig. 8) and experimental dependences of the VSWR input of the four-stages filter (solid line in Fig. 8) shows the same trends as the comparison of similar frequency dependencies for single- and threestages filters: significant differences between the calculated and experimental dependences of the input VSWR. The numerical values of the input VSWR four- stages filter are as follows: the minimum values of the input VSWR in the bandwidth of pass-band from $6.5 \mathrm{GHz}$ to $6.7 \mathrm{GHz}$ are in the range from 1.29 to 1.3 relative units, with the highest values of VSWR for the highest attenuation $|\mathrm{Ku}|$. The maximum values of the input VSWR correspond to the filter locking bands at frequencies of 5, 3...6.4 GHz (lower pass-band) and 6.8...8.5 GHz (upper pass-band) and are in the range of 2 relative units to infinity also with the highest values of the input VSWR for the highest attenuations of the AFC.

\section{Conclusion}

The presented results of the study of the frequency characteristics of the filters on the waveguideslit membranes allow us to hope for further improvement of their frequency-selective characteristics, which is possible, probably, with the use of procedures and programs for the optimization of the studied structures.

Using methods of electrodynamic modeling will allow design such filters with predetermined properties.

In addition, we believe that the filters presented in this paper on waveguide-slot membranes can be the basis for the construction of small-size filters of the mid-centimeter wavelength range, as they have in this range-zone significantly smaller dimensions than the filters on the segments of long lines in the waveguides.

\section{References}

[1] Snyder R.V., Mortazawi A., Hunter I., Bastioli S., Macchiarella G., Wu K. Present and future trends in filters and multiplexers, IEEE Trans. on Microwave Theory and Techniques, 2015, 10, 33243360 .

[2] Addamo G., Orta R., Virone G., Peverini O.A., Taskone R. Radial transmission-line approach for the analyses of ring loaded slots in circular waveguide, IEEE Trans. on Microwave Theory and Techniques, 2015, 5, 1468-1474.

[3] Leal-Sevillano C.A., Montejo-Garai J.R., Ruiz-Cruz J.A., Rebollar J.M. Wideband equivalent circuit for multi-aperture multi-resonant waveguide irises, IEEE Trans. on Microwave Theory and Techniques, 2016, 3, 724-732.

[4] Kopylova N., Kopylov A., Salomatov Y. Experimental investigation of frequency characteristics of the multistage slot membranes waveguide filters, V International Forum for Young Scientists "Space Engineering”, Tomsk, Russia, April 18-20, 2017, MATEC Web of Conferences 102, 01025 (2017). URL: https://doi.org/10.1051/matecconf/201710201025. 